\title{
Molecular characterization of a phytoplasma causing Phyllody in clover and other herbaceous hosts in Northern Italy
}

\author{
Giuseppe Firrao, Luigi Carraro, Emanuela Gobbi and Romano Locci \\ Dipartimento di Biologia Applicata alla Difesa delle Piante, Universita' di Udine, via Scienze 208, 33100 Udine, \\ Italy (Fax: 432558501 )
}

Accepted 27 May 1996

Key words: 16S rDNA, mycoplasmalike organisms, phytopathogenic mollicutes, PCR

\begin{abstract}
Red clover (Trifolium pratense) and Ladino clover (Trifolium repens) plants showing phytoplasma-associated symptoms (yellowing/reddening, virescence and phyllody) have been recovered in Friuli-Venezia Giulia, Italy. Using AluI RFLP analysis of PCR amplified 16S rDNA we showed that the disease can be caused independently by two phylogenetically distinct phytoplasmas. One of them showed the very typical 16S rDNA RFLP pattern of the agent of Clover Phyllody in Canada (CCPh). The 16S rDNA of the other phytoplasma (Italian Clover Phyllody phytoplasma, ICPhp) has been PCR amplified, cloned and sequenced. The sequence revealed high similarity (>98\%) with phytoplasmas belonging to the X disease cluster, which includes organisms not reported to cause phyllody on their hosts. The analysis by AluI RFLP of the PCR amplified pathogen 16S rDNA from other herbaceous plants (Crepis biennis, Taraxacum officinale, Leucanthemum vulgare) collected nearby with phytoplasma-associated symptoms showed similar patterns. Southern blot hybridization of their EcoRI digested total DNA revealed identical RFLP patterns, suggesting that the causative agent may be the same organism.
\end{abstract}

Abbreviations: PCR - Polymerase Chain Reaction; rDNA - gene for the small subunit ribosomal RNA; RFLP Restriction Fragment Length Polymorphism.

\section{Introduction}

The recently introduced trivial name 'phytoplasmas' refers to a group of mycoplasmalike organisms which cause diseases in several hundred plant species (McCoy et al., 1989). Clovers (Trifolium spp.) may be affected by several phytoplasma diseases, which have been named according to the symptoms they induce. The Clover Yellow Edge (CYE) floral symptoms consist of a reduction in colour and size, but never phyllody or virescence (Chiykowski, 1981). Conversely virescence and phyllody are typical symptoms of Clover Phyllody (CPh) (Chiykowski, 1962; Krczal, 1960). The phytoplasmas associated with the named diseases have been transmitted to a variety of experimental hosts, including periwinkle (Catharantus roseus L.), and the symptoms shown on those hosts were consistant with those shown on the natural host (Chiykowski,
$1962,1981)$. In addition to the former ones, clover has been reported to host other phytoplasma diseases (i.e. Clover Proliferation, Chen and Hiruki, 1975), including diseases typical of woody plant such as the $\mathrm{X}$ disease (Chiykowski and Sinha, 1982).

By the introduction of molecular techniques it has been shown that CYE and $\mathrm{CPh}$ are caused by taxonomically distantly related phytoplasmas. In the $16 \mathrm{~S}$ rDNA AluI restriction analysis carried out by Schneider et al. (1993) a European isolate of CPh (KV) showed a pattern identical to typical Aster Yellows strains. In a similar work, Lee et al. (1993) found that a Canadian isolate of $\mathrm{CPh}(\mathrm{CCPh})$ differed from the typical Aster Yellows strains by having an unique pattern due to the absence of an AluI site in only one of its two rRNA genes, while CYE was related to the $\mathrm{X}$ disease phytoplasmas. Finally, Gundersen et al. (1994) examined $\mathrm{CYE}$ and $\mathrm{CCPh}$ by $16 \mathrm{~S}$ rDNA sequencing and assigned 
them to their cluster (iv) (X disease and related strains) and (i) (Aster Yellows and related strains) respectively. These results were in agreement with those obtained by Southern blot hybridization studies (Lee et al., 1992a; Lee et al., 1992b).

While CYE was only recovered in North America, $\mathrm{CPh}$ was reported in Europe (Carraro et al., 1991; Krczal, 1960). It is widely spread in Northern Italy, where $T$. repens and $T$. pratense are often infected. We found that only part of the clover showing phyllody and virescence symptoms in Northern Italy were actually affected by a phytoplasma related to a previously reported agent of $\mathrm{CPh}$ (CCPhp). In this paper we reported the characterization by $16 \mathrm{~S}$ rDNA sequence analysis of the additional phytoplasma which causes Clover Phyllody in Northern Italy and which is called Italian Clover Phyllody phytoplasma (ICPhp).

\section{Materials and methods}

Origin of samples

About 50 samples of clover (Trifolium pratense L. and T. repens L.), Leucanthemum vulgare L., Taraxacum officinale Weber and Crepis biennis L. showing yellowing, virescence and phyllody symptoms were collected during 1992, 1993 and 1994 from different sites in the region Friuli-Venezia Giulia (Italy), mostly from two sites named Cussignacco and Cavazzo Carnico. The phytoplasmas were transmitted from the natural herbaceous host to periwinkles by a dodder bridge (Osler et al., 1994). The following phytoplasma infected periwinkles were also included as reference in the $16 \mathrm{~S}$ rDNA-RFLP study: CCPh phytoplasma $(\mathrm{CCPh})$ (donated by Dr. T.A. Chen, Dept. of Plant Pathology, Rutgers University, New Brunswick), Western X disease phytoplasma (WX), and Aster Yellows phytoplasma (donated by Dr. E. Seemüller, Institut für Pflanzenschutz im Obstbau, Dossenheim, Germany).

\section{DNA extraction and amplification}

Nucleic acids were extracted from $300 \mathrm{mg}$ of plant tissue using previously published methods (Firrao et al., 1993; Firrao and Locci, 1993). Due to the presence of Taq polymerase inhibitors, plants other than clover and periwinkle were extracted with phenol followed by chlorophorm:isoamyl alchol (24:1). The DNA was then recovered using the Gene Clean kit (BIO101, La Jolla, CA). The 16S rDNA amplification by polymerase chain reaction was carried out using the protocol and the primer pair $\mathrm{P} 1 / \mathrm{P} 4$ according to Firrao et al. (1993). Three $\mu \mathrm{l}$ of the PCR products were run on an $1 \%$ agarose gel in the presence of 0.5 $\mu \mathrm{g} \mathrm{ml}^{-1}$ ethidium bromide to quantify the amount of DNA amplified.

The product of the amplification with $\mathrm{P} 1 / \mathrm{P} 4$ spawns a region of the phytoplasma $16 \mathrm{~S}$ rDNA which includes the restriction endonuclease $A l u I$ recognition sites named c, d, e, f, g, and h by Schneider et al. (1993).

\section{Amplified 16S rDNA-RFLP}

Four to $15 \mu 1$ of the PCR product were digested with $5 \mathrm{U}$ AluI endonuclease for three hours and then loaded onto a $1 \%$ GTG $+3 \%$ NuSieve agarose (FMC, Rockland, ME) gel in TBE ( $89 \mathrm{mM}$ Tris-borate, $2 \mathrm{mM}$ EDTA) buffer. The gel was run for $5 \mathrm{~h}$ at $7 \mathrm{Vl} \mathrm{cm}-1$, then stained with ethidium bromide and visualized under UV light.

\section{Cloning and sequencing}

The product of a PCR amplification from ICPh infected periwinkle DNA carried out using primers $\mathrm{P} 1$ and P4 (Firrao et al., 1993) was incubated with 2U of E. coli polymeraseI Klenow fragment (Boehringer Mannheim, Germany) for $15 \mathrm{~min}$ in the presence of 0.1 $\mathrm{mM}$ dNTPs. The reaction was electrophorized on an agarose gel and the $860 \mathrm{bp}$ DNA fragment was purified using the Gene Clean kit (BIO101, La Jolla, CA). It was then ligated to a SmaI-cut pBluescript plasmid vector and transformed in E. coli DH5 $\alpha$ competent cells. A recombinant plasmid was chosen for subcloning and sequencing, which were carried out according to standard techniques (Ausubel et al., 1992). From the resulting sequence a specific oligonucleotide was synthesised and used in conjunction with the primer $\mathrm{P} 1$ of Deng and Hiruki (1991), to amplify a $550 \mathrm{bp}$ fragment corresponding to the $5^{\prime}$-end of ICPh 16S rDNA. This DNA fragment was cloned and sequenced using the same methods used for the $860 \mathrm{bp}$ fragment. The sequence of the $3^{\prime}$-end was obtained together with that of the $16 \mathrm{~S} / 23 \mathrm{~S}$ spacer region (Kirkpatrick et al., 1994) and provided by courtesy of C. Smart (Dept. of Plant Pathology, University of California, Davis, CA).

Sequence analysis was carried out using the package developed by the Genetic Computer Group at the University of Wisconsin (Devereux et al., 1984). The phylogenetic analysis was performed using the bootstrap option of the program PAUP (phylogenetic analysis using parsimony) for Macintosh (Swofford, 1991). 


\section{Chromosomal RFLP}

Total nucleic acids were extracted from the periwinkles infected by the phytoplasma transmitted from infected herbaceous plants (Trifolium repens, Crepis biennis, Taraxacum officinale, Leucanthemum vulgare) using the Doyle and Doyle (1990) method. After RNase treatment and ethanol precipitation, about $5 \mu \mathrm{g}$ of total DNA were digested with $10 \mathrm{U}$ EcoRI for $4 \mathrm{~h}$, then loaded in an 1\% agarose gel in TBE buffer and run for $12 \mathrm{~h}$ at $2.5 \mathrm{~V} \mathrm{~cm}^{-1}$. The Southern blot was carried out according to the standard protocol (Ausubel et al., 1992) and the hybridization with digoxigeninlabelled probes following the manufacturer's instruction (Boehringer Mannheim, Germany). A mixture of 4 Western $X$ disease phytoplasma cloned chromosomal fragments (Kirkpatrick et al., 1987), kindly supplied by B.C.Kirkpatrick (University of California, Davis, $\mathrm{CA}$ ), was used as the probe.

\section{Results}

\section{$16 S$ rDNA-RFLP}

The PCR amplification of DNA extracted from symptomatic clover plants using the primer pair $\mathrm{P} 1 / \mathrm{P} 4$ resulted in the amplification of DNA fragments of about 860 bp (not shown). The amplification products were then digested with $A l u \mathrm{I}$ restriction endonuclease and the samples subdivided into two different groups according to the RFLP pattern obtained. The first group (lane 3 of Figure 1) included the samples which gave a RFLP pattern similar to that obtained by digestion of the PCR amplified 16S rDNA of the CCPhp (lane 5 of Figure 1), and the second group (lane 2 of Figure 1) the samples with RFLP patterns similar to that of the WXp (lane 6 of Figure 1). All the samples collected from the site of Cussignacco showed a RFLP pattern of the second group. The samples collected in the site of Cavazzo Carnico showed RFLP patterns of both groups in 1992, but only of the first group in 1994 (no symptomatic clover samples could be collected in 1993 from this site). In one of the samples from Cavazzo Carnico, a RFLP pattern consistent with a double infection was detected (lane 4 of Figure 1).

\section{Phylogenetic position of ICPh}

The entire 16S rDNA of ICPh was cloned and sequenced. The sequence was submitted to the GenBank-EMBL database with the accession number $X 77482$. The comparison with recently obtained sequences of the $16 \mathrm{~S}$ rDNA of various phytoplasmas

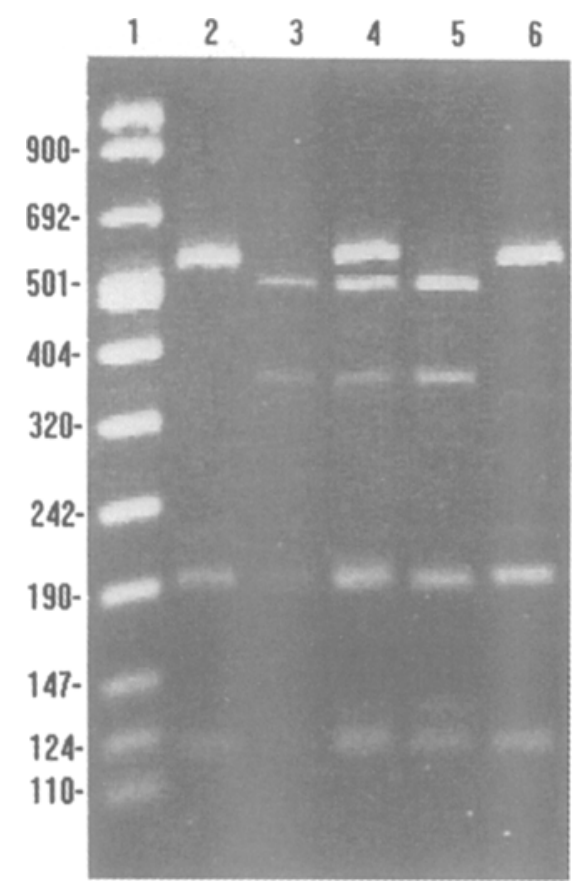

Figure 1. Agarose gel electrophoresis of the Alul digestion of PCR amplified DNA extracted from different clover (lanes 2, 3 and 4) and periwinkle (lane 5: CCPh infected; lane 6: WX infected) plants. Lane 1: molecular weight marker.

(Gundersen et al., 1994; Kuske and Kirkpatrick, 1992; Lim and Sears, 1989; Namba et al., 1993; Seemüller et al., 1994) indicated high similarity with WXp, blueberry witches' broom phytoplasma (VACp), tsuwabuki witches' broom phytoplasma (TWp) and CYEp, ranging from $98.30 \%$ (with WXp) to $98.85 \%$ (with VACp). Although the significant number of differences suggests that ICPh should be taken as a different organism from CYEp (98.33\% similarity), the phylogenetic analysis using PAUP showed that these two phytoplasmas isolated from clover are phylogenetically closely related (Figure 2 ).

\section{Symptoms on clover and periwinkle}

The two phytoplasmas causing Clover Phyllody in Northern Italy could not be distinguished by symptom evaluation on the natural host. The early symptoms were the yellowing/reddening of leaves, followed by virescence and phyllody. However differential symptoms were observed when both phytoplasmas were transmitted to periwinkle: ICPh infected plants had elongated leaves, while those infected by the $\mathrm{CCPh}$ related phytoplasma had round leaves. A detailed description of the symptoms caused on natural and 


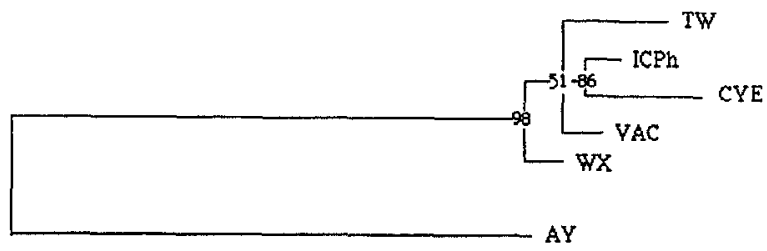

Figure 2. Phylogram resulting from bootstrap parsimony anylisis of $16 \mathrm{~S}$ rDNA sequences of selected phytoplasmas. Numbers are bootstrap values. TW $=$ Tsuwabuki witches' broom (accession no. DI2580); ICPh = Italian Clover Phyllody (accession no. X77482); $\mathrm{CYE}=$ Clover Yellow Edge (accession no. L33766); VAC $=$ Blueberry witches' broom (accession no. X76430); WX $=$ Western $\mathrm{X}$ disease (accession no. L04682).

experimental hosts by the phytoplasmas isolated from herbaceous hosts in Friuli-Venezia Giulia is given elsewhere (Osler et al., 1994). The phytoplasmas from the donor plant and the periwinkle were identical as confirmed by $16 \mathrm{~S}$ rDNA-RFLP (not shown).

\section{Host range of $I C P h$}

The same AluI PCR-RFLP pattern obtained from ICPh infected clover was also generated by the digestion of the amplification products obtained from DNA extracted from Leucanthemum vulgare, Taraxacum officinale and Crepis biennis which occurred in the same area (not shown). The associated phytoplasmas were transmitted to periwinkles where symptoms similar to those caused by ICPh were produced (Osler et al., 1994). Identical RFLP patterns were also obtained by hybridization of the EcoRI digested DNA with a cocktail of cloned chromosomal fragments of WXp (Figure 3). Conversely the RFLP pattern of the WXp was completly different, suggesting that the genetic differences among ICPh and WXp were significant.

\section{Discussion and conclusion}

In the past years certain biological properties such as host induced symptom expression and vector specificity have been regarded as useful tools to distinguish phytoplasmas (Chiykowski and Shina, 1990; Kirkpatrick, 1991; Marwitz, 1990). More recently the taxonomy of this group of fastidious prokaryotes has been revised on the basis of the results obtained by nucleic acid hybridization and 16S rRNA sequencing (Davis et al., 1988; Gundersen et al., 1994; Seemüller et al., 1994). As a rapid method for distinguish phytoplasmas, the restriction endonuclease digestion of PCR

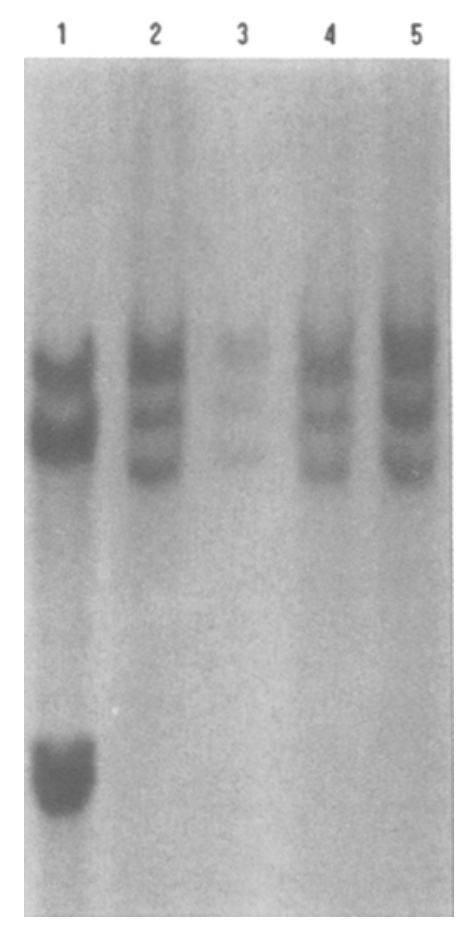

Figure 3. Southern blot hybridization of $E c o$ RI digested DNA from periwinkle infected by WXp (lane1), and phytoplasmas transmitted from Leucanthenum vulgare (lane 2), Taraxacum officinale (lane 3), Trifolium repens (lane 4) and Crepis biennis (lane 5).

amplified 16S rDNA has been suggested and widely applied (Lee et al., 1993; Schneider et al., 1993).

By the use of AluI PCR-RFLP we showed here that the clover plants with symptoms of phyllody found in Northern Italy can actually be infected by two phylogenetically different phytoplasmas. One of the two phytoplasmas could be easily identified because it showed the very typical pattern of $\mathrm{CCPh}$. This pattern is unique among the strains examined to date, its peculiarity being that the sum of the fragments derived from the $A l u \mathrm{I}$ digestion exceeded the size of the amplified fragment. In the case of the amplification with the primer pair $\mathrm{P} 1 / \mathrm{P} 4$ the sum of the digested fragments is $1370 \mathrm{bp}$ instead of the expected $860 \mathrm{bp}$. It has been suggested that this is due to the presence in the $\mathrm{CCPh}$ chromosome of two 16S rRNA genes whose sequence differs in correspondence of an $A l u \mathrm{I}$ site (Lee et al., 1993). The second phytoplasma causing phyllody on clover appeared to be a newly discovered phytoplasma and it was classified, as suggested by the Subcommittee on the Taxonomy of Mollicutes of the International Committee on Systematic Bacteriology (Tully, 1993), by 16S rDNA sequence analysis. 
It resulted to belong to the WXp cluster as defined by Seemuller et al. (1994), but clearly distinct from the other representatives of thise group. The phytoplasmas belonging to $\mathrm{X}$ disease cluster have been found predominantly in North America; their presence in Europe seemed to be restricted to the blueberry witches brooms phytoplasma. Recently several additional phytoplasmas have been identified which appear to be related to the WXp cluster on the basis of $16 \mathrm{~S}$ rDNA- RFLP studies (Griffiths et al., 1994; Gundersen et al., 1996), but none of them is of European origin. Conversely, the ICPhp appears to be widely spread in Northern Italy. In a survey of plant pathogenic phytoplasmas infecting weeds in Friuli Venezia Giulia carried out using AluI PCR-RFLP, several species were found infected by phytoplasma of the WXp cluster (Osler et al., 1994). Three of them, examined in this study, showed identical RFLP patterns when hybridized with a cocktail of four WXp chromosomal fragments. It is therefore likely that ICPh is very actively spread by insect vectors to many different plant species.

The WXp cluster includes phytoplasmas not known to cause phyllody on their host plant. Although the presence of phyllody seemed to be restricted to some well characterized groups of phytoplasmas (Aster Yellows, Sunhemp Phyllody), more recent molecular information had given limited support to the hypothesis that differences in symptom expression can actually reflect substantial taxonomic differences (Lee et al., 1992a; Schneider and Seemüller, 1994). The results reported herein showed that two only distantly related phytoplasma may naturally infect and cause phyllody in the same host in the same geographic area. It is also interesting to note that the two phytoplasma may be found together in the same plant and that the organism phylogenetically closest to ICPhp is the CYEp, another clover pathogen. These findings suggest that virescence and phyllody may be the result of the expression of a limited genetic pool, which could be transmitted horizontally to phylogenetically distant phytoplasmas sharing the same hosts. The finding that both the phytoplasmas examined in this study can be transmitted experimentally by the leafhopper Euscelidius variegatus (L: Carraro, unpublished results) further supports this hypothesis.

\section{Aknowledgements}

We thank Dr. E. Seemüller (Institut für Pflanzenschutz im Obstbau, Dossenheim, Germany) and Dr. T.A. Chen (Dept. of Plant Pathology, Rutgers University, New Brunswick) for providing phytoplasma infected periwinkles and B.C.Kirkpatrick (University of California, Davis, CA) for providing cloned probes. Research supported by National Research Council of Italy, Special project R.A.I.S.A., Sub-project N. 2 Paper N. 2780

\section{References}

Ausubel FA, Brent R, Kingston RE, Moore DD, Seidman JG, Smith JA and Struhl K (1992) Current Protocols in Molecular Biology. Greene Publishing and Wiley-Interscience, New York

Carraro L, Osler R, Refatti E and Poggi Pollini C (1988) Transmission of the possible agent of apple proliferation to Vinca rosea by dodder. Riv Pat Veg, S IV 26: 43-52

Chen MH and Hiruki C (1975) Electron microscopy of mycoplasmalike bodies associated with clover proliferation disease. Proc Am Phytopathol Soc 2: 52

Chiykowski LN (1962) Clover phyllody virus in Canada and its transmission. Can J Bot 40: 397-404

Chiykowski LN (1981) Association of mycoplasma-like organisms with clover yellow edge disease. Can J Plant Pathol 3: 139-144

Chiykowski LN, and Sinha RC (1982) Herbaceous host plants of peach eastern X-disease agent. Can J PLant Pathol 4: 8-15

Chiykowski LN and Sinha RC (1990) Differentiation of MLO diseases by means of symptomatology and vector transmission. In: Stanek G, Cassell G, Tully JG and Whitcomb RF (eds) Recent Advances in Mycoplasmology. Proceedings of the 7th Congress of the International Organization for Mycoplasmology (pp. 280287) Gustav Fisher Verlag, Stuttgart

Davis RE, Lee I-M, Dally EL, Dewitt N and Douglas SM (1988) Cloned nucleic acid hybridization probes in detection and classification of mycoplasmalike organisms (MLOs). Acta Hort 234: $115-121$

Deng $S$ and Hiruki C (1991) Amplification of 16S rRNA genes from culturable and nonculturable Mollicutes. J Microbiol Meth 14: 53-61

Devereux J, Haeberli P and Smithies O (1984) A comprehensive set of sequence analysis programs for the VAX. Release 7. Nucleic Acid Res 12: 387-395

Doyle JJ and Doyle JL (1990) Isolation of plant DNA from fresh tissue. Focus 12(1): 13-15

Firrao G, Gobbi E and Locci R (1993) Production of oligonucleotide probes for mycoplasma-like organisms using the polymerase chain reaction. Phytopathology 83: 602-607

Firrao G and Locci R (1993) Rapid preparation of DNA from phytopathogenic mycoplasma-like organisms for polymerase chain reaction analysis. Letters in Appl Microbiol 17: 280-281

Griffiths HM, Gundersen DE, Sinclair WA, Lee IM and Davis RE (1994) Mycoplasmalike organisms from milkweed, goldenrod and spirea represent two new I6S rRNA subgroups and three new strain subclusters related to Peach X disease MLO. Can J Plant Pathol 16: 255-260 
Gundersen DE, Lee IM, Rehner SA, Davis RE and Kingsbury DT (1994) Phylogeny of mycoplasmalike organisms (phytoplasmas) - $\mathbf{a}$ basis for their classification. J Bacteriol 176: 5244 5254

Gundersen DE, Lee IM, Schaff DA, Harrison NA, Chang CJ, Davis RE and Kingsbury DT (1996) Genomic diversity and differentiation among phytoplasma strains in 16S rRNA groups I (Aster Yellows and related phytoplasmas) and III ( $X$-disease and related phytoplasmas). Int J Syst Bacteriol 46: 64-75

Kirkpatrick BC (1991) Mycoplasma-like organisms: Plant and invertebrate pathogens 4050-4067, In: Balows A, Trüper HG, Dworkin M, Harder W and Schliefer KH (eds) The Prokaryotes. 2nd ed. Springer-Verlag Press, New York

Kirkpatrick B, Smart C, Gardner S, Gao J-L, Ahrens U, Maurer R, Schneider B, Lorenz K-H, Seemüller E, Harrison N, Namba S and Daire X (1994) Phylogenetic relathionships of plant pathogenic MLOs established by $16 / 23 \mathrm{~S}$ rDNA spacer sequences. IOM Letters 3: 228-229

Kirkpatrick BC, Stenger DC, Morris TJ and Purcell AH (1987) Cloning and detection of DNA from a nonculturable plant pathogenic mycoplasma-like organism. Science 238: 197-200

Kuske CR and Kirkpatrick BC (1992) Phylogenetic relationships between the western aster yellows mycoplasmalike organism and other prokaryotes established by $16 \mathrm{~S}$ rRNA gene sequence. Internat J Systematic Bacteriol 42: 226-233

Krczal H (1960) A virosis transmissible from white clover to Fragaria vesca. $Z$ Pflkrankh 67: 599-602

Lee IM, Davis RE, Chen TA, Chiykowski LN, Fletcher J, Hiruki C and Schaff DA (1992a) A genotype based system for the identification and classification of mycoplasmalike organisms (MLOs) in the aster yellows MLO strain cluster. Phytopathology 82: 977-986

Lee IM, Gundersen DE, Davis RE and Chiykowski LN (1992) Identification and analysis of a genomic strain cluster of mycoplasmalike organisms associated with canadian peach (eastern) X-disease western X-disease and clover yellow edge. J Bacteriol 174: 6694-6698

Lee I-M, Hammond RW, Davis RE and Gundersen DE (1993) Universal amplification and analysis of pathogen 16S rDNA for classification and identification of mycoplasma-like organisms. Phytopathology 83: 834-842
Lim P-O and Sears BB (1989) 16S rRNA sequence indicates that plant-pathogenic mycoplasmalike organisms are evolutionarily distinct from animal mycoplasmas. J Bacteriol 171: 5901-5906

Marwitz R (1990): Diversity of yellows disease agents in plant infections In: Stanek G, Cassell G, Tully JG and Whitcomb RF (eds) Recent Advances in Mycoplasmology. Proceedings of the 7th Congress of the International Organization for Mycoplasmology (pp. 431-434) Gustav Fisher Verlag, Stuttgart

McCoy RE, Cauldwell A, Chang CJ, Chen TA, Chiykowski LN, Cousin MT, Dale JL, de Leeuw GTN, Golino DA, Hackett KJ, Kirkpatrick BC, Marwitz R, Petzold H, Sinha RC, Sugiura M, Whitcomb RF, Yong IL, Zhu BM and Seemüller E (1989) Plant diseases associated with mycoplasma-like organisms. In: Whitcomb RF and Tully JG (eds) The Mycoplasmas, Vol V (pp. 545-640) Academic Press, New York

Namba S, Oyaizu H, Kato S, Iwanami S and Tsuchizaki T (1993) Phylogenetic diversity of phytopathogenic mycoplasmalike organism. Int J Syst Bacteriol 43: 461-467

Osler R, Firrao G, Carraro L, Loi N, Musetti R and Chen TA. (1994) Biodiversity of plant MLOs in a well definited ecological area. IOM Letters 3: 286-287

Schneider B, Ahrens U, Kirkpatrick BC and Seemüller E (1993) Classification of plant-pathogenic mycoplasma-like organisms using restriction-site analysis of PCR-amplified $16 \mathrm{~S}$ rDNA. J Gen Microbiol 139: 519-527

Schneider B and Seemüller E (1994) Studies on taxonomic relationships of mycoplasma-like organisms using Southern blot analysis. J Phytopathol 141: 173-185

Seemüller E, Schneider B, Maurer R, Ahrens U, Daire X, Kison H, Lorenz KH, Firrao G, Avinent L, Sears BB and Stackebrandt E (1994) Phylogenetic classification of phytopathogenic mollicutes by sequence analysis of $16 \mathrm{~S}$ ribosomal DNA. Int J Syst Bacteriol 44: 440-446

Swofford DL (1991) Phylogenetic Analysis Using Parsimony, Version 3.1. Computer program distributed by the Illinois Natural History Survey, Champaign, Illinois, USA

Tully JC (1993) International Committee on Systematic Bacteriology Subcommittee on the Taxonomy of Mollicutes. Minutes of the interim meetings, 1 and 2 Aug. 1992, Ames, Iowa. Int J Syst Bacteriol 43: 394-397 